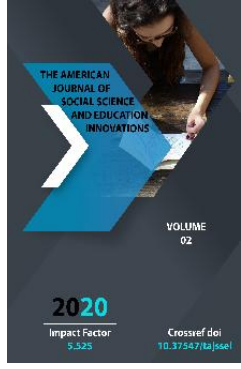

\section{Modern Information Technologies - A Factor Of Increasing Youth Education, Potential And Spirituality}

\author{
Zulfiyaxon Aripova Solijonovna \\ Associate Professor, Candidate Of Philosophical Sciences, Department Of "Humanities" , \\ Andijan Machine Building Institute, Uzbekistan
}

Journal Website: http://usajournalshub.c om/index,php/tajssei

Copyright: Original content from this work may be used under the terms of the creative commons attributes 4.0 licence.

\title{
ABSTRACT
}

The article points out that the improvement of teaching technologies depends on the appropriate use of modern information and communication networks in the learning process.

\section{KEYWORDS}

Information communication, information technology, information, spirituality, science and technology, enlightenment, computer, telecommunications, personality, intellectual, objectivity, materialization, marketing, business technology, extensive, investment, informatization, distance learning.

\section{INTRODUCTION}

In recent years, as a result of the development of science and technology, information and communication, advanced countries have made significant progress in various aspects of society.
These changes and innovations have penetrated into all spheres of education and production in Uzbekistan during the years of independence. In some areas of the use of modern information technologies in higher 
education, our country is one of the leading countries in the world.

Currently, a number of conferences dedicated to the analysis and development of new information technologies in educational standards are held regularly in countries around the world.

The main conclusion of the conferences and exhibitions is that the application of new information technologies in higher education and industry is accelerating the quality of education, its individualization and the transition of society to the stage of informatization. This article addresses the issue of the priority of three main technological areas in education today:

- Development and creation of a fundamentally new teaching methodology that allows the use of SD-ROM technical capabilities of educational materials, computer resources (text, graphics, color 3D-images, animation, video clips, sound, music and music control);

- Introduction of distance learning in the educational process on the basis of new information technologies, independent management of students and a specific new form of distance learning;

- Pay special attention to the use of modern telecommunications and information network technologies in education.

Researcher Itiel de Sol Tul explains the essence of these directions: "Information is valuable not only because of its rapid processing (computerization), but also because it can reach every point of the globe in a timely manner under critical conditions" [1]

Such an intensive function of information in education constitutes inter-sectoral systems.
These three main components, mentioned above, have a special role in the management of higher education and lead to positive changes in the educational process, affecting the ability of its participants to acquire independent knowledge. It should be noted that information is a concept that represents an important part of objective reality and is manifested in material systems designed for self-preservation, processing and use of the results (traces) of impact. [2] Objectivity, materialization, and the ability to transmit are important features of information.

"The study of information is inextricably linked with the analysis of the information management process, because information exists in it as a functional property." [3]

\section{THE MAIN PART}

It is known that there is another important area of (information) information technology that affects people, which is directly related to the educational process. E. Zhukov, a researcher of re-impact technologies in the information society, explains: "Information technology (Ne Teeh), emerging high humanitarian technology (Nigh-Hume), as well as political technologies affecting the sociocultural sphere, RR-technology, marketing, business -technology and emerging independent socio-cultural phenomena.»[4] Along with the positive side of these technologies, there are also certain risks. The danger is that as the process of strong external pressure and influence on the minds of people increases, the management of information and knowledge also becomes associated with changes in the minds of people.

In this sense, it can be said that changes in socio-economic relations are certainly 
reflected in the education system, including higher education. Accordingly, S.X. The following views of Karpennov can be fully agreed upon. "Education and upbringing, which determine the moral potential of man and society, play an important role in positive changes in the human mind. [5] This is not in vain, of course. Because "the intellectual and innovative revolution has further increased the role of education not only in the traditional education system but also in improved the internal system of education.

A sharp intellect is necessary for a learner to learn to read in a very short time. Because education has become the main "technology" in human life. Higher education in particular has the following complex problems that are difficult to solve today:

- Excessive flow of knowledge and limited training time in higher education;

- - unity of science and knowledge and at the same times its division into fundamental and practical types;

- -increased process of integration of education, but its effectiveness is low.

Analyzing the causes of these processes, the following results were obtained when a survey of 1,300 Reuter's experts were conducted to determine the effectiveness of the information and communication issues acquired in the education of Russian scientists.

$25 \%$ uncertainty in the amount of employee information;

$38 \%$ said it took a long time to get important information;

$41 \%$, excessive working conditions;
$47 \% \mathrm{i}$, data search, separating it from its main work;

$48 \%$ fear that the Internet will turn information into "mobile";

$49 \%$ have limited access to information;

94\% expressed confidence that the situation would improve.

Similar analyzes, as reported in a 2002 UNESCO report, $74 /$ of the European community "diagnosed" these aspects of information "information fatigue syndrome info phobia."

In addition to the shortcomings in the mechanism of information exchange, the impact of the processes associated with the increase in the period of spiritual obsolescence of informed information (previously 1-2 years, now 10-15 years) is significant.

Consequently, the content of the management of educational processes in the system of higher education also includes, first of all, such criteria as reliability, scientificity of the received information. In other words, the effective uses of information and communication technologies based on scientific results are important. This means that there must be a balance between education and the management of scientific activity.

The organization of scientific activity in our country, the laws of its implementation, the tendencies in this area, the lack of study of various forms of incentives, complicate the effective management of educational and scientific activities. During the transition period, “... as reforms deepen, the old approaches preserved in the system of 
organization of scientific and technological activities have a negative impact on the technological development of the country, reducing the effectiveness of scientific and technological opportunities. This is reflected in the ongoing attempts to plan science, the inability of science and consumers to find mechanisms of mutual interest in scientific results that require modern market relations, the lack of objective and independent expertise of scientific programs and technological developments. As a result, "... the incompatibility of the organizational structure of scientific and technical activities with modern conditions, the inability to direct intellectual and material resources to the implementation of major scientific programs and technological projects, the lack of alternatives to the proposed scientific programs hinders scientific and technological improvement slows down the development.» Without diminishing the importance of the achievements in accelerating the development of science and technology in the country, in addition to the above, the following problems, in particular, negative trends in the development of some areas of research, unsatisfactory incentives for scientific activity, the current state of material and technical base of scientific institutions. It should be noted that the number of patents and licenses obtained by scientists and engineers remains unchanged from year to year. The reason for this is the formation of a mechanism aimed at alienating science from itself in the system of production that emerged during the Soviet government's leadership of the economy. There is reason for this thesis to occur. For many years there have been two parallel realities in production: first, that production had and relied on cheap labor; secondly, because most of the goods produced are scarce, the work of highly qualified specialists, scientists, who are in demand for any products made by enterprises, the results of their fundamental research are not used on the shelves of the Science and Technology Committee.

The costly economy and the development of science and technology were incompatible with each other. At that time, a strange situation arose: a holistic, centralized science was divided into sections: academic science, network science, research in higher education, and the unity and continuity between them was broken. The second half of the 1980 s and the early 1990s (early years of the transition period) saw the state fail to pursue an integrated science and technology and investment policy. As a result, the country has fallen into a situation where it has become clear that almost 90 percent of the products it produces are not competitive in the world market.

For many years, science in our country has developed on the model of extensive reproduction, the development of new areas of research has been carried out due to the increase in the number of researchers, and staff turnover is mainly determined by the retirement of employees. The negative role of this situation was reflected in the slowdown in the growth of the number of researchers, the failure to master a number of areas of science, a sharp decline in the share of young researchers.

The flagship of the creation and widespread use of high technology in the world is still in the United States, followed by Japan. EU countries are also approaching. In recent years, countries such as South Korea, Singapore, Hong Kong and Taiwan have also joined the competition in the high-tech market. These countries have increased their share of global high-tech exports from 1 to $9 \%$ 
over the past 20 years.

- Development of intellectual and creative abilities of the person; - to be able to improve the skills of each member of society and change the field of activity;

- Create conditions for accelerated learning and increase the effectiveness of distance learning.

Distance learning did not happen suddenly and completely. The development process was gradual. With the emergence of new technologies of education, as they were applied to the distance education system, its various forms have evolved. So far, however, it has taken the form of a model based on fully multimedia materials that include different generations of distance learning technologies and multimedia. All of this is the result of technologies complementing each other, not replacing each other.

If we look at the history of the development of distance education, it has already manifested itself in the XIX century with the distribution of written and printed materials by mail. This system is called "courses by mail" and students are provided with textbook, textbooks, a list of additional literature. In these courses, the student returns written answers to the questions and through it is remotely checked and evaluated by the teacher. With the advent of radio (1920s) and television (1950s), these "new" information and communication technologies brought a new form to distance learning.

Distance learning (DL) is a process that connects teachers and students located in different geographical regions, and interactions are carried out using special technologies. Different methods are used in the implementation of communication: the exchange of typographic printed materials by mail and telefax, audio conferencing, video conferencing, virtual conferencing by computer. It is natural that there is a growing demand for distance education among those who live far from the university, do not have the conditions to attend, those who want to improve their skills, the disabled and others who for various reasons do not have direct access to higher education. Distance learning is a very convenient tool, especially for busy adults and those who want to study in a second specialty.

Distance learning can be described as learning that is characterized by five main conditions:

- Presence of the teacher and the student and the existence of mutual agreement between them;

- Educational institution and the teacher are at a certain distance from each other with the student;

- Bilateral dialogue between teacher and student;

- Availability of special materials for distance learning;

- Both parties are provided with computers and other equipment and communications.

The distance learning process has introduced into the field of education not only new pedagogical and information technologies, but also a number of new concepts and terms:

- Virtual class (group);

- Training;

- Educational telecommunication projects;

- Feedback;

- Dialogue technology;

- Computer communication;

- Teleconference;

- Coordinator, moderator, teleconferencing facilitator, tutor. 
Virtual class (group) - A generalization of the joint actions of students through computer networks in the performance of learning tasks.

Teaching support is the ability of a teacher in distance learning to assist a student remotely through a variety of learning materials and information.

A learning telecommunications project is a collaborative (collective) activity of students aimed at achieving a common goal. In this case, the student is not given a goal of a learning nature, but a goal that models scientific or production activities. At the same time, it helps students develop skills such as teamwork and division of labor. Important features of the educational telecommunications project:

- Its time and duration (from a few weeks to 2-3 months);

- All participants of the project, which creates a virtual classroom, use computer telecommunications networks and software to exchange information;

- The need for a clear organization of student activities by the project coordinator.

Feedback in distance learning is the flow of information sent by a teacher to a student as a result of the teacher's assessment of distance student activities. In this process, the educator expresses his attitude to the student's mastery and evaluates his performance. Timely and rationally organized feedback leads to the formation of a position of sustainable stimulation of teaching activities. In traditional teaching, feedback can be easily learned by the teacher through the intonation of the voice, various mimic gestures. Remote feedback is also important in the organization and planning of distance learning, as many verbal opportunities for teacher and student in education are limited. Dialog technology is a combination of software, devices, as well as interactions and activities of individuals in the establishment of free communication.

Teleconferencing is a way for stakeholders to exchange various information and messages. Distance education is now entering a new stage of development worldwide. This is mainly due to the fact that the basic technologies and methods of teaching remain unchanged, mainly due to the development of new technical means and their level of public capabilities.

If in the 8os the technology of teaching materials and their delivery for distance learning, the technology of communication between teacher and student was much simpler, decades later the situation has completely changed with the introduction of new technical and technological means. Distance learning has included a variety of interactive tools such as microwave television, radiography, compressed video, teleconferencing, and audio conferencing. Among them, more recent digital technologies have begun to be used in distance education. It integrates hypermedia programs, allowing the student to directly control the level of mastery of the learning materials. However, it can connect and use a common database, video courses, audio materials, and other software via the Internet or other networks at its convenience, from home or work.

It should be noted that in the XXI century, an improved form of human information technology has created nanotechnology. Nano is a prefix to units of measurement that defines one in a billion, for example, one 
nanometer is one billionth of a meter. Nano is derived from the Greek word "Nanos", which means dwarf. Nanotechnology is a tiny technology, the prototype of which is embodied in nature. Invisible bacteria, ant spiders and similar insects are natural Nano bodies.

Scientists predict that in 2020, Nano-clothes that will save a person from a car accident, lift the mood, inform which part of the body is unhealthy, they are expected to be sold in ordinary stores, will be able to install a new globalized communication system. Shortly before the end of 2020, the first military uniforms were created to divert the bullets fired from enemy pistols. [7]

\section{CONCLUSION}

Thus, with the advent of computers, a new stage in the development of media began. Man is trying to overcome the psychological limitations of his body by means of technical means, loading information technology with mental labor, information processing and even some abstract thinking functions. The emergence of modern information technology is based on the advanced achievements of science and technology - the electronics industry, communication technology and audio-visual technology. Informatics embodied a new relationship between science and industry.

\section{REFERENCES}

1. Itel de Sol Tul. Using the tools of technology freedom. $M$ :, NIIVO, 2004, p37

2. N.A.Shermuhammedova. Research methodology. Textbook. Tashkent 2014. p-352
3. B. Turaev. Informational property of space and time // Natural Science and Philosophy. III international seminar. - St. Petersburg: 1992. -- p-64

4. Zhukov E. Sociocultural reality. Higher education in Russia - 2006, No. 11-p-86-94

5. Karpenko S.Kh. Spiritual and moral guidelines and modern civilization. / Higher education today-2006, No. 29, p20-27

6. Ortiqov A. Problems of development of science and rapid introduction of high technologies in Uzbekistan, Journal of Economics and Education, №2, T., 2005, p-17-18.

7. N.A.Shermuhammedova. Research methodology. Textbook. Tashkent 2014. p-377 